UCRL-ID-129920

\title{
Second Quarter Results of Chemical Measurements in the Single Heater Test
}

\author{
W. Glassley \\ L. DeLoach
}

April 17, 1997

This is an informal report intended primarily for internal or limited external distribution. The opinions and conclusions stated are those of the author and may or may not be those of the Laboratory.

Work performed under the auspices of the U.S. Department of Energy by the Lawrence Livermore National Laboratory under Contract W-7405-Eng-48. 


\section{DISCLAIMER}

This document was prepared as an account of work sponsored by an agency of the United States Government. Neither the United States Government nor the University of California nor any of their employees, makes any warranty, express or implied, or assumes any legal liability or responsibility for the accuracy, completeness, or usefulness of any information, apparatus, product, or process disclosed, or represents that its use would not infringe privately owned rights. Reference herein to any specific commercial product, process, or service by trade name, trademark, manufacturer, or otherwise, does not necessarily constitute or imply its endorsement, recommendation, or favoring by the United States Government or the University of California. The views and opinions of authors expressed herein do not necessarily state or reflect those of the United States Government or the University of California, and shall not be used for advertising or product endorsement purposes.

This report has been reproduced directly from the best available copy.

Available to DOE and DOE contractors from the Office of Scientific and Technical Information

P.O. Box 62, Oak Ridge, TN 37831

Prices available from (615) 576-8401, FTS 626-8401

Available to the public from the

National Technical Information Service

U.S. Department of Commerce

5285 Port Royal Rd.,

Springfield, VA 22161 


\title{
SECOND QUARTER RESULTS OF CHEMICAL MEASUREMENTS IN THE SINGLE HEATER TEST
}

\author{
ACCOUNT TR3E2FB2 \\ HEATING PHASE OF SINGLE HEATER TEST \\ MILESTONE SP9240M4
}

William Glassley and Laura DeLoach

Lawrence Livermore National Laboratory 
SP9240M4: Second Quarter Results of Chemical Measurements in the Single Heater Test

William Glassley and Laura DeLoach

Lawrence Livermore National Laboratory

\section{INTRODUCTION}

In the first quarter report, comparison was made between measured water compositions obtained from Hole \#16, interval 4 (16-4), and preliminary simulations of that water chemistry. This report describes additional data collected since that sampling, as well as the results of refined simulations that provide a better approximation of the reaction path followed by the water. Also, during this period waters were extracted from pads placed on SEAMIST liners in boreholes specifically for chemical sampling. Several pads exhibited evidence of having collected moisture, so they were removed and the water analyzed. However, for reasons discussed below, analytical problems were encountered. $\Lambda$ s a result, refined sampling techniques will be used in the future Drift Scale Test, when employing sample pads on the liners.

\section{TECHNIQUE}

Several pads were observed to contain visible water (\#SPC00521115 and SPC00521117). Water extraction from these pads was accomplished by immersing the pads and their respective container bags in measured volumes of deionized water, after the wet pads were weighed. The pads were allowed to exchange their water with the deionized water for three days. The water was then sampled and analyzed. The pads were then dried and weighed. The mass difference, and the known dilution factor provided data sufficient to reconstruct the fluid composition. A blank was also used, in which an unused sample of the same pad fabric was weighed and immersed in deionized water, and the water analyzed. The concentrations of the sample waters was corrected using the analyses of the blank water, assuming that the blank provided baseline values for the amount of ion extracted from the cloth per gram of material. However, during the course of analysis it was determined that the blank material was not from the same production run as the material used in the sampling pads. As a result, a correction for the blank contribution to the 
solution could not be assured to be reliably relevant to these analyses. Hence, the results are not reported here. Further evaluation is underway to determine the significance of the results. In the future, the manufacturing lot of the samples will be determined, and blanks obtained from those specific lots, in order to assure accurate results.

\section{MODELING STRATEGY}

Simulations conducted in the initial report assumed flow pathways were through tuff, rather than through fractures, and also assumed that the water would be in equilibrium with atmospheric gases. These assumptions were made assuming that sampling pads contacting borehole walls would most likely collect water from that portion of the rock that had the largest exposed surface area of pad contact, which would be matrix material, and that the dominant gas species would be derived from atmosphere components, and would evolve very little.

The water obtained from 16-4 was found to be entering at a rate far exceeding that expected for matrix flow. Hence, flow must be primarily via fractures, rather than matrix. In addition, the low $\mathrm{pH}$ measured for the sample is inconsistent with water-air equilibrium. For these reasons, new simulations were done assuming fracture flow, and allowing variation in gas composition.

Fracture mineralogy was assumed to be $90 \%$ calcite and 5\% opal (modeled as amorphous $\mathrm{SiO}_{2}$ ), with minor exposed $\mathrm{K}$-feldspar and albite, as rock components. These proportions are consistent with published reports of fracture mineralogy (Carlos, 1987, 1989, 1994; Lin and Daily, 1984; Lin, 1991; Lin et al., 1995), and observations made on samples obtained from the Large Block Test (Glassley and Boyd, 1995). These mineral phases were considered because they represent the primary sources and sinks for the principal cations and anions in the solution. Future simulations will consider those minor coexisting phases that may contribute additional components to the water.

It was also assumed that $\mathrm{H}_{2} \mathrm{O}$ and $\mathrm{CO}_{2}$ were the dominant gas components. These assumptions were made to satisfy the observations that the water has chemical properties consistent with condensate flowing along fracture surfaces, but it has sufficiently interacted with tuff to acquire isotopic characteristics requiring a role for the primary rock-forming minerals (feldspars). Furthermore, previous work has suggested that $\mathrm{CO}_{2}$ may play an important role in the evolution of the gas phase during boiling (Arthur and Murphy, 1989; Crescenti and Arthur, 1991). The low pH observed for these waters is consistent with this observation, hence, $\mathrm{CO}_{2}$ evolution was considered in these simulations. Additional 
simulations in the future will consider the effects of other gas and solid components, particularly those that may affect the redox conditions within the system.

The time duration of the simulation covered a period of up to two months, since the time between initiation of the heater test and sampling was ca. 90 days. It was assumed that an insufficient volume of water would be heated to result in significant condensate shedding until at least a week of heating had elapsed.

The primary variables for the simulations were reaction rate constants for the solids of concern, and the partial pressure of $\mathrm{CO}_{2}$. The rate constants were varied within the uncertainty envelope of the values that generated the best results for simulations of the plug flow reactor experiments (for a description of these experiments and the results, see Johnson et al., 1997). A matrix of simulations, discussed below, was constructed in order to evaluate which combination of variables would provide the best match with the observed water compositions.

The simulations were conducted using version 7.2a of the EQ3/6 code package (Wolery, 1992 a,b; Wolery and Daveler, 1992) and the R22a "com" database.

\section{RESULTS}

\section{Chemical Analyses}

The chemical analyses of the SHT 16-4 water completed since the last report are shown in Table 1 as bold type. Also, shown for comparison are analyses of saturated zone waters from wells $J-13$ and G-4, and fracture waters collected from Rainier Mesa (abbreviated Rain. Mesa).

The $\mathrm{pH}$ measurement was obtained from waters collected approximately 30 days after the initial samples were taken. This measurement, therefore, can only be considered an approximation of the $\mathrm{pH}$ of the original water. This discrepancy reflects the fact that the original samples were collected during an unanticipated "window of opportunity" in which water appeared in a hole not designed for chemical sampling. As a result of this experience, procedures are now in place to assure timely measurement of $\mathrm{pH}$ when samples are collected.

The $\mathrm{HCO}_{3}$ - value shown for the sample was computed from charge balance, assuming the $\mathrm{pH}$ measurement corresponded to the actual hydrogen ion activity at the time of sampling. However, the $\mathrm{HCO}_{3}{ }^{-}$indicated for the $\mathrm{EQ} 3 / 6$ simulation was that computed assuming the $\mathrm{CO}_{2}$ partial pressure was 0.1 bars. 
TABLE 1: Analyses of Hole 16 Water, And Comparison With Other Waters

\begin{tabular}{|c|c|c|c|c|c|c|c|c|}
\hline & $\begin{array}{r}16-4 \\
\text { LLNL } \\
\end{array}$ & log molal & $\begin{array}{r}16-4 \\
\text { LANL } \\
\end{array}$ & $\begin{array}{c}16-4 \\
\text { USGS }^{* *}\end{array}$ & $\begin{array}{c}\mathrm{EQ} 3 / 6 \\
\text { Model ** }\end{array}$ & $\mathrm{J}-13 *$ & $\mathrm{G}-4^{*}$ & $\begin{array}{c}\text { Rain. Mesa } \\
\text { Water }\end{array}$ \\
\hline $\mathrm{Na}(\mathrm{mg} / \mathrm{l})$ & 16 & -3.16 & & & 16.1 & 45.8 & 57 & 35 \\
\hline $\mathrm{Si}(\mathrm{mg} / \mathrm{l})$ & 16.8 & -3.22 & & & 19 & 28.5 & 21 & 25 \\
\hline $\mathrm{Ca}(\mathrm{mg} / \mathrm{l})$ & 13 & -3.49 & & & 13.2 & 13 & 13 & 8.4 \\
\hline $\mathrm{K}$ (mg/l) & 2.5 & -4.19 & & & 2.46 & 5 & 2.1 & 4.7 \\
\hline $\mathrm{Mg}(\mathrm{mg} / \mathrm{l})$ & 1.63 & -4.17 & & & n.e. & 2.01 & 0.2 & 1.5 \\
\hline $\mathrm{pH}$ & 6.2 & & & & 6.08 & 7.4 & 7.7 & 7.5 \\
\hline $\mathrm{HCO}_{3}(\mathrm{mg} / \mathrm{l}) \#$ & 84.4 & -2.86 & & & & 129 & 139 & 98 \\
\hline $\mathrm{F}(\mathrm{mg} / \mathrm{l})$ & 0.44 & -4.64 & & & & 2.18 & 2.5 & 0.25 \\
\hline $\mathrm{Cl}(\mathrm{mg} / \mathrm{l})$ & 2.54 & -4.14 & 2.1 & & & 7.1 & 5.9 & 8.5 \\
\hline$S(\mathrm{mg} / \mathrm{l})$ & 0.71 & -4.65 & & & & & & \\
\hline $\mathrm{SO}_{4}(\mathrm{mg} / \mathrm{l})$ & 1.83 & -4.72 & 1.5 & & & 18.4 & 19 & 15 \\
\hline $\mathrm{PO}_{4}{ }^{3}(\mathrm{mg} / \mathrm{l})$ & $<0.03$ & & & & & $<10$ & & \\
\hline Nitrite (mg/l) & $<0.01$ & & & & & & & \\
\hline $\mathrm{NO}_{3}{ }^{-}(\mathrm{mg} / \mathrm{l})$ & 1.1 & -4.75 & & & & 8.8 & & \\
\hline $\operatorname{Li}(\mathrm{mg} / \mathrm{l})$ & $<0.03$ & & & & & 0.048 & 0.067 & \\
\hline $\mathrm{B}(\mathrm{mg} / \mathrm{l})$ & 0.37 & -4.47 & & & & 0.134 & & \\
\hline $\mathrm{Al}(\mathrm{mg} / \mathrm{l})$ & $<0.06$ & & & & & 0.02 & & \\
\hline $\mathrm{Fe}(\mathrm{mg} / \mathrm{l})$ & 0.74 & -4.88 & & & & & & \\
\hline $\mathrm{Sr}(\mathrm{mg} / \mathrm{l})$ & 0.2 & -5.64 & & 0.0022 & & 0.04 & & \\
\hline $\mathrm{Br}(\mathrm{mg} / \mathrm{l})$ & $<0.02$ & & 0.008 & & & & & \\
\hline del D & & & & & & -98 & -103 & \\
\hline $\mathrm{del}^{18} \mathrm{O}$ & & & & & & -13 & -13.8 & \\
\hline Tritium & $0.44 \pm$ & & & & & & & \\
\hline${ }^{87} \mathrm{Sr} /{ }^{\beta 6} \mathrm{Sr}$ & 0.19 TU & & & 0.7124 & & & & \\
\hline
\end{tabular}

* Frori Harrar et al., 1990

\# Computed from charge balance; see text

** EQ3/6 simulations discussed in text

n.e. not evaluated

\#\# Reported by Z. Peterman, 3/1 1/97

\section{Simulations}

The results of the simulations are shown in Table 2 and Figure 1. The measured values for the 16-4 water are indicated by arrows in Figure 1. The best match between the simulated and measured compositions is indicated by tick marks attached to the symbols in Figure 1. Note that the vertical scale in Figure 1 is in units of $\mathrm{mg} / \mathrm{l}$ for $\mathrm{Si}, \mathrm{Na}$, and $\mathrm{K}$, only. The $\mathrm{pH}$ values refer to the same axis, but are unitless.

Table 2 indicates the rate constants used for each simulation. Note also that precipitation of specific mineral phases was suppressed during the simulations (column labeled "Suppressed"). For the silica polymorphs, suppression of the indicated phases (tridymite, quartz, and chalcedony) is necessary in order to approach the elevated silica 
concentrations observed in the analyses, which indicates that the borehole waters are supersaturated in these silica polymorphs. Suppression of talc is also required, and reflects the commonly observed phenomenon that talc supersaturation is a persistent occurrence in these waters.

\section{DISCUSSION AND CONCLUSIONS}

The chemical analyses confirm previous observations that these waters are more dilute than those observed previously at the site. They also confirm that, although the water is almost certainly derived from condensation of water vapor derived from heating of pore waters near the heater, they have reacted with the rock and fracture lining minerals to generate a dilute water similar in character to that seen in well $\mathrm{J}-13$.

The concentration of $\mathrm{Si}$ in the water is below saturation with respect to cristobalite, but is supersaturated, with respect to quartz, tridymite, and chalcedony. This is the only ion that shows significant discrepancy between observed and simulated values. However, this may provide evidence that precipitation of one or more of the supersaturated (i.e., "suppressed") minerals is occurring slowly in the borehole. If this were the case, it would be expected that the water composition in the hole would approach some steady-state silica concentration that would be appropriate for the precipitating phase.

The low $\mathrm{pH}$ of this water, the relative abundances of the major ions, and the time period over which it formed require that the coexisting $\mathrm{CO}_{2}$ partial pressure must have been elevated, relative to ambient atmospheric values, by approximately two orders of magnitude. Analyses in progress suggest this is consistent with the expected evolution of the gas phase coexisting with ambient pore waters interacting with tuff during heating to ca. $120-150^{\circ} \mathrm{C}$. The third quarter report will provide a description of these results.

\section{REFERENCES}

Arthur, R.C., and W.M. Murphy, 1989, An Analysis of Gas-Water-Rock Interactions

During Boiling in Partially Saturated Tuff, Sci. Geol. Bulletin, vol. 42, \#4, p. 313-327.

Carlos, B., 1987. Minerals in fractures of the saturated zone from drill core USW G-4, Yucca Mountain, Nye County, Nevada. LA-10927-MS. Los Alamos National Laboratory, Los Alamos, New Mexico. 32p. 
Carlos, B., 1989. Fracture-coating minerals in the Topopah Spring Member and Upper Tuff of the Calico Hills from drill hole J-13. LA-11504-MS. Los Alamos National Laboratory, Los Alamos, New Mexico. 20p.

Carlos, B., 1994. Field guide to fracture-lining minerals, Yucca Mountain, Nevada. LA12803-MS. Los Alamos National Laboratory, Los Alamos, New Mexico. 12p.

Criscenti, L.J., and R.C. Arthur, 1991, The Calculated Effects of Isothermal Boiling on Tuff-Water Interactions, Radiochimica Acta, v. 52/53, p. 513-517.

Glassley, W.E., and Boyd, S., 1995. Preliminary description of small block mineralogical features, data report. Yucca Mountain Site Characterization Project Milestone M0L062.

Harrar, J., Carley, J.F., Isherwood, W.F., and Raber, E., 1990. Report of the committee to review the use of J-13 well water in Nevada Nuclear Waste Storage Investigations. Lawrence Livermore National Laboratory, UCID-21867.

Johnson, J.W., Knauss, K.G., and Glassley, W.E., 1997. Rcactive transport through Topopah Spring tuff: Summary of initial PFR experiments and associated computer simulations, Yucca Mountain Site Characterization Project Milestone SPL1BM4, Lawrence Livermore National Laboratory, Livermore, CA.

Lin, W., 1991. Variation of permeability with temperature in fractured Topopah Spring Tuff samples. Proceedings, 2nd Annual Int. Conf. on High Level Radioactive Waste Management, Las Vegas, NV, April 28 - May 3, 1991 (American Nuclear Society, La Grange Park, IL). p. 988-993.

Lin, W. and Daily, W., 1984. Transport properties of Topopah Spring Tuff. Lawrence Livermore National Laboratory, Livermore, CA. UCRL-53602.

Lin, W., Roberts, J.J., Glassley, W.E., and Ruddle, D., 1995. The effect of rock-water interaction on permeability. Lawrence Livermore National Laboratory, Livermore, CA. UCRL-JC-119574. 
Wolery, T.J., 1992a, EQ3/6, A Software Package for Geochemical Modeling of Aqueous Systems: Package Overview and Installation Guide. Lawrence Livermore National Laboratory, Livermore, CA UCRL-MA-110662 PT. I

Wolery, T.J., 1992b, EQ3NR, A Geochemical Program For Aqueous SpeciationSolubility Calculations: Theoretical Manual, User's Guide, and Related Documentation. Lawrence Livermore National Laboratory, Livermore, CA UCRL-MA-110662 PT. III

Wolery, T.J., and S. A. Daveler, 1992, EQ6, A Computer Program for Reaction Path Modeling of Aqueous Geochemical Systems: Theoretical Manual, User's Guide, and Related Documentation (Version 7.0). Lawrence Livermore National Laboratory, Livermore, CA UCRL-MA-1 10662 PT. IV

\section{FIGURE CAPTION}

Figure 1: Simulated water compositions, for the conditions listed in Table 2. The arrowed values that fall on the $\mathrm{Ca}=13.0 \mathrm{mg} / \mathrm{l}$ are the measured concentrations of the $16-4$ water. The ticked values are those for the simulation identified as "Selected" in the table, and which are printed in bold faced type. 


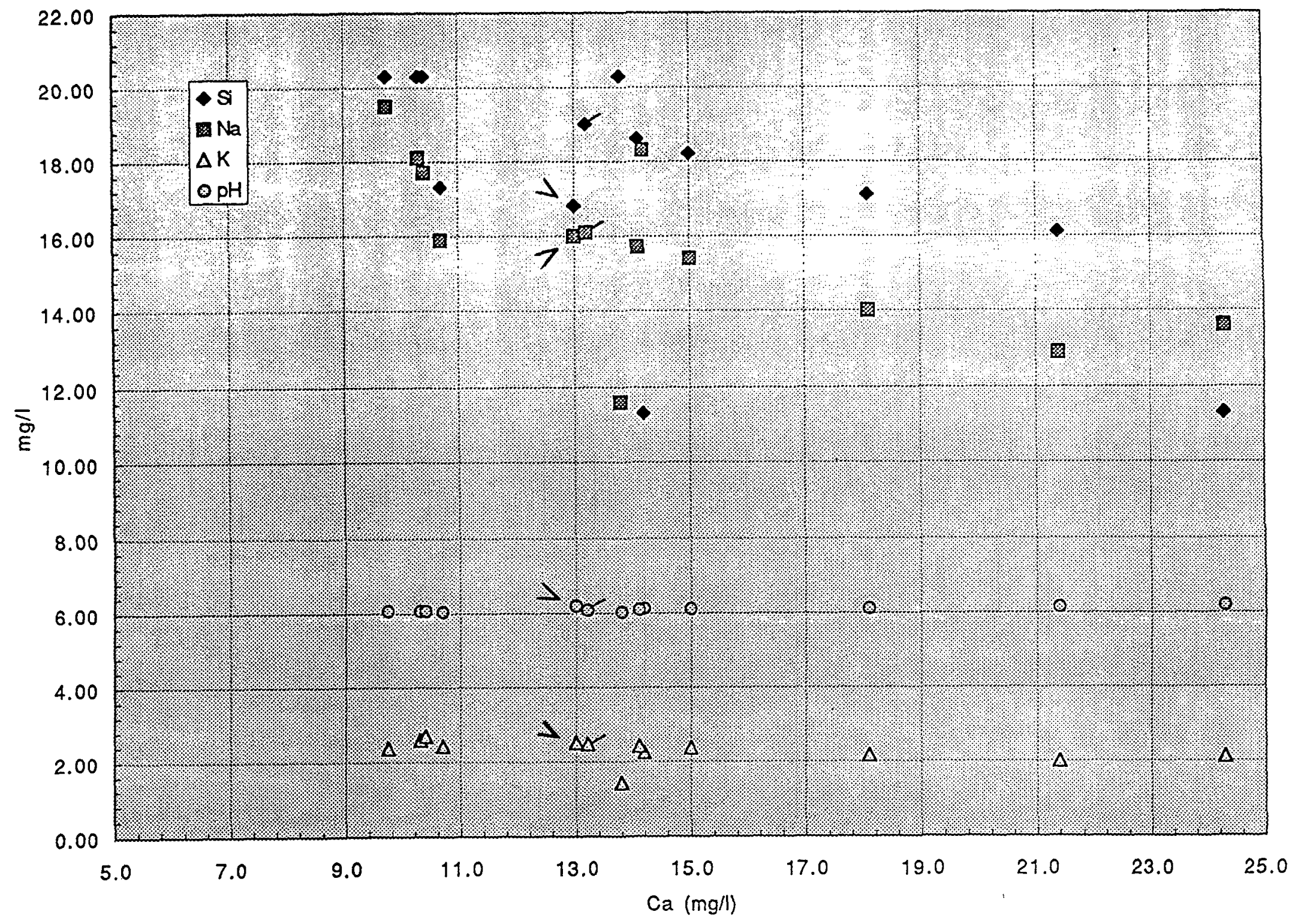


TABLE 2

\begin{tabular}{|c|c|c|c|c|c|c|c|c|c|c|c|}
\hline & \multirow[b]{2}{*}{ Ca mgn } & \multirow[b]{2}{*}{ Si mgn } & \multirow[b]{2}{*}{$\mathrm{Na} \mathrm{mg} / \mathrm{l}$} & \multirow[b]{2}{*}{$\mathrm{K} \mathrm{mg/1}$} & \multirow[b]{2}{*}{$\mathrm{pH}$} & \multirow[b]{2}{*}{ Days } & \multicolumn{4}{|c|}{ Rates } & \multirow{2}{*}{$=\frac{\log }{b}$} \\
\hline & & & & & & & Calcite* & Cristobalite* & Albite & K-spar & \\
\hline \multirow[t]{11}{*}{ Observed } & 13 & 16.8 & 16 & 2.5 & 6.2 & & & & & & \\
\hline & 24.3 & 11.3 & 13.6 & 2.9 & 6.19 & 21.7 & $3.00 E-14$ & $3.90 E-13$ & $7.90 \mathrm{E}-13$ & $3.60 E-14$ & \\
\hline & 14.2 & 19.3 & 18.3 & 2.23 & 6.12 & 23.07 & $3.00 E-15$ & $6.00 E-13$ & $1.00 E-12$ & $3.60 E+14$ & \\
\hline & 13.8 & 20.3 & 11.6 & 1.4 & 6.02 & 14.55 & $3.00 \mathrm{E}-15$ & $6.00 E-13$ & $1.00 E-12$ & $3.60 E-14$ & \\
\hline & 9.74 & 20.3 & 19.5 & 2.36 & 6.07 & 25.02 & $3.00 E-15$ & $6.00 E-13$ & $1.00 E-12$ & $3.60 E-14$ & \\
\hline & 10.3 & 20.3 & 18.1 & 2.59 & 6.06 & 27.63 & $8.00 \mathrm{E}-15$ & $3.00 \mathrm{E}-13$ & $8.50 E-13$ & $3.60 E-14$ & \\
\hline & 18.1 & 17.1 & 14 & 2.16 & 6.12 & 22.9 & $3.00 E-14$ & $1.00 E-13$ & $8.00 E-13$ & $3.60 E-14$ & \\
\hline & 10.4 & 20.3 & 17.7 & 2.69 & 6.06 & 28.79 & $1.00 E-14$ & $1.00 E-13$ & $8.00 E-13$ & $3.60 E-14$ & \\
\hline & 15 & 18.2 & 15.4 & 2.35 & 6.1 & 25.09 & $2.20 E \cdot 14$ & $5.00 E-14$ & $8.00 E-13$ & $3.60 E-14$ & \\
\hline & 21.4 & 16.1 & 12.9 & 1.98 & 6.15 & 21 & $4.00 E-14$ & $4.00 E-14$ & $8.00 E-13$ & $3.60 E-14$ & \\
\hline & 14.1 & 18.6 & 15.7 & 2.41 & 6.09 & 25.68 & $2.00 E-14$ & $4.00 E-14$ & $8.00 E-13$ & $3.60 E-14$ & \\
\hline \multirow[t]{3}{*}{ Selected } & 13.2 & 19 & 16.1 & 2.46 & 6.08 & 26.27 & $1.80 E-14$ & $4.00 E-14$ & $8.00 E-13$ & $3.60 E-14$ & \\
\hline & 10.7 & 17.3 & 15.9 & 2.43 & 6.04 & 26.26 & $1.80 E-14$ & $4.00 E-14$ & $8.00 E \cdot 13$ & $3.60 E-14$ & \\
\hline & 10.7 & 17.3 & 15.9 & 2.43 & 6.04 & 26.26 & $1.80 E-14$ & $4.00 \mathrm{E}-14$ & $8.00 E-13$ & $3.60 E-14$ & \\
\hline
\end{tabular}

- mol/am2-sec

* T=Tak, Trid=Tridymite, Qtz=Quartz, ChalcdzChalcedony, Kaol=Kaolinite, Ca-Nont=Ca-rich Nontronite 


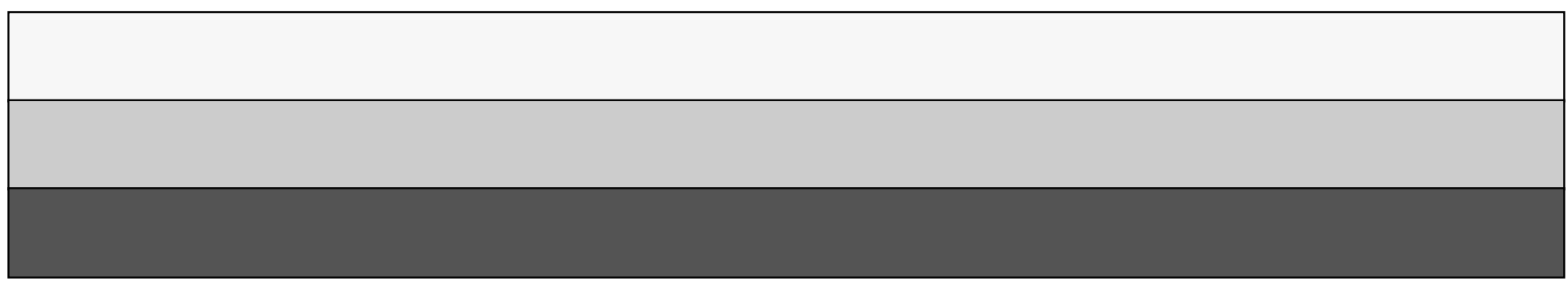

